\title{
Urgences
}

\section{J'écris parce que...}

\section{Françoise Daigle}

Numéro 15, octobre 1986

Épigraphiques

URI : https://id.erudit.org/iderudit/025277ar

DOI : https://doi.org/10.7202/025277ar

Aller au sommaire du numéro

Éditeur(s)

Urgences

ISSN

0226-9554 (imprimé)

1927-3924 (numérique)

Découvrir la revue

Citer ce document

Daigle, F. (1986). J'écris parce que... Urgences, (15), 8-8.

https://doi.org/10.7202/025277ar

Ce document est protégé par la loi sur le droit d'auteur. L’utilisation des services d'Érudit (y compris la reproduction) est assujettie à sa politique d'utilisation que vous pouvez consulter en ligne.

https://apropos.erudit.org/fr/usagers/politique-dutilisation/
Cet article est diffusé et préservé par Érudit.

Érudit est un consortium interuniversitaire sans but lucratif composé de l’Université de Montréal, l'Université Laval et l'Université du Québec à Montréal. Il a pour mission la promotion et la valorisation de la recherche. https://www.erudit.org/fr/ 


\section{Françoise Daigle}

J'écris parce que je ne veux pas des mots que je trouve: par soustraction.

Roland Barthes: Le plaisir du texte

J'écris parce que je ne veux pas des mots que je cherche. Ils tombent lourds - à froid, à plat, roulent péniblement dans le caniveau des idées mortes (requiescat in pace). Ah, il pleut c'est sûr c'est gris c'est morne ça cliquète en clichés qui s'agglutinent.

J'additionne je fais fausse route

J'écris parce que je ne veux pas des mots qui me cherchent. Les fantômes courent sur des mers d'encre. Les tournesols comme des soleils morts tourmentés de giboulées tardives et le remords et cela meurt encore de toutes parts - les maux justes qui tombent comme des guillotines bien alignés

L'addition toujours serveur faites vite qu'on en finisse enfin

J'écris parce que je ne vaux pas les mots que je trouve

M'anticipent impitoyablement la si opaque transparence des mots

Et reprendre le fil déchu la trame le fichu tissu le drame entre les...

Je crie parce que je ne vis pas des mots que je...

Des mots comme des petites aiguilles blanches douloureuses qui se bousculent à la fenêtre de petits vampires tenaces accrochés aux ongles incroyablement bavards têtus oui entêtés même médiocres

J'écris sous la menace

Par abandon par précaution par réaction

Par rémission par conviction par passion

Peut-être même par prétention 